\title{
The control and visualisation system in an intelligent building
}

\author{
Rafat Nowak $^{1}$, Aleksandra Pietrasz ${ }^{1}$, and Grzegorz Trzmiel ${ }^{1, *}$ \\ ${ }^{1}$ Poznan University of Technology, Faculty of Electrical Engineering, Piotrowo 3A, 60-965 Poznan, Poland
}

\begin{abstract}
This publication contains the description of the design of PLC-based comfort control system, interoperating with the safety system, whereby the said interoperation is subject to the master control and visualisation that uses the SCADA software. The introduction presents the description of the respective elements integrated into one system. Further on, the paper includes design assumptions and the principle of operation of the comfort control system. The article ends with conclusions.
\end{abstract}

\section{Introduction}

\subsection{Programmable logic controllers}

PLC's are microprocessor-based systems which are used to control processes and actuators in automation systems. Because of the wide array of applications and the easiness in the adaptation to the controlled process, they have gained much popularity $[1,2,3,4]$.

\subsection{Intelligent building}

The function of an intelligent building is to ensure the maximum efficiency in its functioning, as well as the comfort and safety of the user by making the most of the available resources, which entails the reduction in the costs of operation $[5,6,7,8]$.

\subsection{SCADA systems}

The term SCADA defines the software which ensures the possibility of master process control and data processing in real time. The visualisation of the controlled process or model in this type of software consists of the connection of the graphics on synoptic screens with the defined set of variables $[1,2,9]$.

\section{System design}

\subsection{Design assumptions}

The function of the system is to ensure comfort and safety to users of a residential building. The task of the comfort management system is to control the lighting, heating, cooling and anti-burglary roller blinds, and it also cooperates with a separate alarm system - the intrusion and hold-up system with additional fire, gas and flood detectors. In the case of all the comfort control subsystems, there is an option of the master control, using the SCADA software [10,11].

\subsection{Operation of the system}

\subsubsection{Lighting}

The lighting is controlled using presence sensors, lighting intensity sensors and wall switches - the lighting is switched on in rooms depending on the condition of the three-position switch, therefore it is possible to switch on/off the lighting on a permanent basis and leave it in the automatic mode (fig.1) [11].

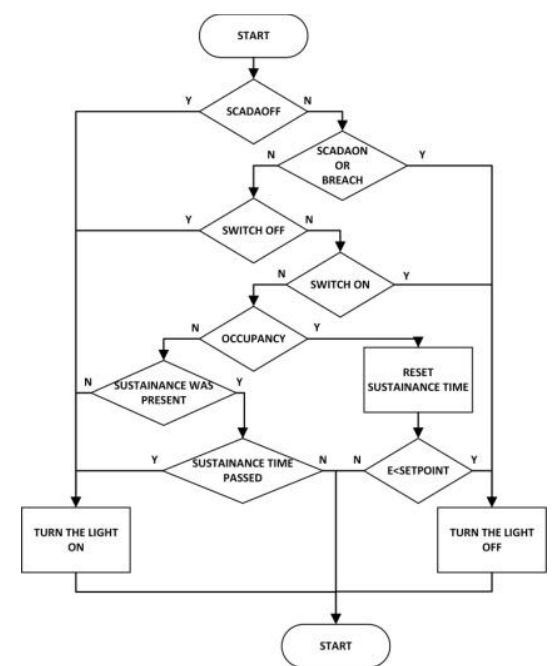

Fig. 1. Lighting control algorithm in rooms [11].

A mono-stable switch is used in other rooms, while in the bathrooms and in corridors, the lighting intensity criterion was not taken into consideration. Furthermore, the lighting is switched on in the case of violation of protected zones [11].

Corresponding author: grzegorz.trzmiel@put.poznan.pl 


\subsubsection{Heating and cooling}

The surface heating system uses coils with hot water installed in floors and walls of rooms, while the cooling system uses coils with cold water installed in ceilings (cooling ceilings). It is possible to support the operation of the cooling system by using anti-burglary roller blinds [11].

The heating and cooling systems are controlled using the pulse-width modulation (PWM) in the living room and the on/off modulation in other rooms. The algorithm presented in fig. 2 depicts the diagram of the cooling system operation in the living room [11].

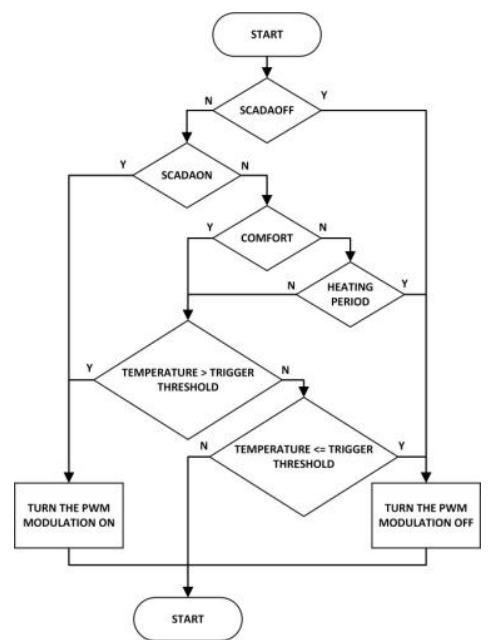

Fig. 2. Control algorithm for the operation of the cooling system in the living room. [11]

\subsubsection{Roller blind control}

The roller blinds are controlled using switches, signals from the alarm system, temperature and rain sensors, the current roller blind position and the hour taken from the real time clock built in the controller [11]. A part of the control programme responsible for the operation of the anti-burglary roller blinds was provided using the sequential function chart - SFC. The use of the SFC enables the creation of the control sequences based on steps, in which actions are performed, and transition - conditions of switching between the respective steps. In the case of such a type of control, the switching to a given step takes place only upon fulfilment of the condition specified in the transition. - by that time the programme may only perform an action described in the current step [11].

\subsection{Visualisation}

In order to monitor the system operation, the SCADA software with the visualisation based on synoptic screens was used. As well as the view of the current status of the comfort control system in the building, the SCADA software allows for the control of its respective functions, e.g. the positioning of the roller blinds in a certain manner, or the switching on of the lighting [10]. Owing to the creation of the users, the access control to the respective system functionalities is provided [10].

\section{Summary}

The reliance of the comfort control system in the building on the PLC enables its adaptation to the individual needs of the user. On top of this, the universality of such a controller allows for its interoperation with other systems based on popular analogue and digital data transmission standards. All the subsystems interoperating in one control system may be covered by the visualisation, including the master control via the SCADA software. This shows that the systems, which were created for industrial purposes may easily be transferred to the commercial applications, which allows for the creation of the building automation system at a limited budget - the solutions designed taking into account the intelligent building are often more expensive and less universal.

\section{References}

1. J. Kasprzyk, Programowanie sterowników przemystowych, (Wyd. Naukowo-Techniczne, Warszawa, 2006)

2. J. Kwaśniewski, Sterowniki PLC $w$ praktyce inżynierskiej, (Wyd. BTC, Legionowo, 2008)

3. T. Legierski, J. Kasprzyk, J. Wyrwał, J. Hajda, Programowanie sterowników PLC, (Wyd. Pracowni komputerowej Jacka SKALMIERSKIEGO, Gliwice, 1998)

4. J. Jajczyk, A. Dobrzycki, M. Filipiak, D. Kurz, E3S Web Conf. 19, 01027 (2017)

5. D. Clements-Croome, Intelligent Buildings: Design, Management and Operation, (Thomas Thelford Publishing, Londyn, 2004)

6. L. Kasprzyk, A. Tomczewski, K. Bednarek, A. Bugała, E3S Web of Conferences 19, 01030 (2017)

7. A. T. P. So, W. K. Chan, Intelligent Building Systems, (Kluwer Academic Publishers, Norwell, 1999)

8. S. Wang, Intelligent Buildings and Building Automation, (Spon Press, Nowy Jork, 2010)

9. G. Trzmiel, Eksploatacja i Niezawodnosc Maintenance and Reliability 19/4, 516 (2017)

10. R. Nowak, Wizualizacja sterowania procesami $w$ budynku inteligentnym, Master's thesis, Poznan University of Technology, Poznan (2017)

11. A. Pietrasz, Sterowanie systemami komfortu $w$ budynkach inteligentnych, Master's thesis, Poznan University of Technology, Poznan (2017)

Corresponding author: grzegorz.trzmiel@put.poznan.pl 